\title{
POLITIK ISLAM MONGOLIA: Mencermati Strategi Ekspansi Timur Lenk
}

\author{
Oleh: M. Hadi Masruri \\ Fakultas Tarbiyah UIN Maliki Malang \\ Email: hadimasruri@ymail.com, HP. 085855789998
}

\begin{abstract}
Abstrak
Pada dasarnya makalah ini membincang sepak terjang Timur Lenk yang berambisi menguasai dunia lewat pendirian Imperium Mongol Raya sebagaimana misi yang pernah dicanangkan oleh buyutnya Jenghis Khan dan Hulagu Khan. Timur Lenk sendiri tetap melanjutkan tradisi invasi bangsa Mongolia yaitu tidak memaksakan agama ataupun praktek spiritualitasnya terhadap bangsa yang ditaklukkannya, justru mereka membangun negeri taklukannya dengan prinsip kedaerahan. Bahkan pada akhirnya Raja Mongolia yang berbalik memeluk agama Islam termasuk Timur Lenk sendiri pada akhir abad ke-13 dan awal abad ke-14. Kemudian Ideologi Mongolisme menjadi platform utama dalam menaklukkan seluruh negara dengan kekuatan kerajaan dan militer. Ada dua kerangka dasar bangsa Mongolia dalam menancapkan kekuasaan militernya, seperti yang dilakukan oleh Timur Lenk yaitu: pertama, teori geneolis: hegemoni dunia untuk melanggengkan Imperium Mongol Raya dengan garis komando kekuatan militer dan menjalankan politik absolutisme kuno yakni percaya bahwa semakin besar kekuasaan penguasa maka peluang perdamaian dan keamanan akan tercapai. Kedua, teori attack and defend: membangun kembali negara yang telah dihancurkannya dengan infrastuktur yang luar biasa seperti istana megah, pengembangan ilmu pengetahuan, sejarah, dan tasawuf lalu berusaha mempertahankannya.

Kata Kunci:Mongolia, Timur Lenk, Jenghiz Khan
\end{abstract}

\section{Abstract}

This paper discusses Timur Lenk who is ambitious to dominate the world through the founding of the great Mongol Empire as a mission ever launched by the grandchildren of Genghis Khan and Hulagu Khan. Timur Lenk himself continued the tradition of the Mongolian invasion force that is not forcing religion or spiritual practices to a conquered nation; they even build the conquest countries with the principle of regionalism. Even, in the end, the King of Mongolia turned to Islam, including Timur Lenk himself at the end of the 13th century and early 14th century. Then Mongolism Ideology becomes a major platform in conquering the entire countries with the royal and military strength. There are two basic frameworks of the Mongolian nation in its military power expansion, as the one done by Timur Lenk: first, the geneolis theory: the world hegemony to perpetuate the Mongol Empire using military force and running the ancient absolutism politic believing that the greater authority of the ruler could result on achieving peace and security. Second, attack and defend theory: rebuilding a country that has been 
destroyed with luxurious infrastructures like an extraordinary magnificent palace, developing science, history, Sufism and then try to defend them.

Keywords: Mongolia, Timur Lenk, Jenghiz Khan

\section{Pendahuluan}

Salah satu tokoh penting dalam perjalanan sejarah Islam abad pertengahan (1250-1500 M) adalah pada zaman kekuasaan bangsa Mongolia. Hal ini setidaknya karena dinasti Ilkhan (Armstrong, 2002:134) dari bangsa Mongolia tampil ke peta wilayah Islam secara kontroversial. Di satu sisi, dihujat secara tajam karena kebengisan dan kebiadabannya terhadap segala jenis penghuni wilayah yang diukuasainya beserta seisi peradabannya, yang oleh karenanya kekuasaan Baghdad runtuh, bahkan lenyap dibumihanguskan. Di sisi yang lain, permulaan yang kejam di bawah tangan besi Hulagu Khan akhirnya juga membawa angin baru bagi perluasan wilayah Islam itu sendiri. Hal ini terutama ketika anak cucu keturunan Hulagu Khan secara perlahan memeluk Islam, (Syalabi, 1979: 745) yakni raja ketiga dari dinasti Mongolia, Ahmad Teguder (1282-1284 M), yang kemudian diikuti oleh raja ketujuh, Mahmud Ghazan (1295$1304 \mathrm{M}$ ) dan raja-raja selanjutnya adalah pemeluk agama Islam (Hasan,1989: $307)$.

Bangsa Mongol berasal dari daerah pegunungan Mongolia, yang membentang dari Asia Tengah sampai ke Siberia Utara, Tibet Selatan, Manchuria Barat, dan Turkistan Timur. Nenek moyang mereka bernama Alanja Khan, yang mempunyai dua putra kembar: Tartar dan Mongol. Dari kedua putra ini lahir dua suku bangsa besar Tartar dan Mongol. Mongol mempunyai anak bernama Ilkhan, yang melahirkan keturunan bangsa Mongol, termasuk sang penakluk Hulagu Khan (Hasan,1989:307).

Menurut Lapidus, Sejarah masyarakat Islam di Asia Tengah ini, sejak periode Mongol sampai periode kontemporer, pada garis besarnya dapat dibagi menjadi tiga wilayah: yakni wilayah padang rumput bagian Barat dan Utara, yakni wilayah Golden Horde dan penggantinya, Kazakh; Turkestan (nama modern bagi 
Transoxania dan beberapa wilayah di sekitarnya) yang merupakan pusat dinasti Timuriyah dan pemerintahan Uzbek pada masa sesudahnya; dan wilayah sebelah Barat Turkestan, yakni daerah perkotaan kabilah di sekitar oases, yang menjadi propinsi Cina Singkiang pada akhir abad Sembilan belas, (Lapidus, 1999:639642)

Dari sekian banyak pemimpin-pemimpin besar bangsa Mongolia, ada empat yang dipandang paling terkemuka: a) Jenghis Khan (1206-1227 M); b) Hulagu Khan (1256-1265 M); c) Timur Lenk (1370-1404 M, dan d) Zhahiruddin Babur (1526-1558).

Makalah ini tidak hendak mendeskripsikan ketokohan keempat pemimpin Mongolia tersebut, melainkan hanya berupaya memotret sosok kontroversial penerus dinasti Chaghatai, yakni Timur Lenk, yang sepak terjangnya banyak dihujat dan sekaligus dipuja oleh banyak kalangan, yang justru mirip dengan pendahulunya para pendiri dinasti bangsa Mongolia, Jenghiz Khan dan Hulagu Khan. Terutama pada strategi politiknya, yang meskipun telah memeluk Islam, namun kebiadaban dan kebengisannya tetap mewarisi trah nenek moyangnya.

\section{Latar Kehidupan Timur Lenk}

Menurut (Lewis,1993:197) tokoh berdarah campuran Mongol Turki yang ini lahir di kota Kech (sekarang Khakhrisyabz, "kota hijau", Uzbekistan), daerah Selatan Samarkand wilayah Qashka Darya Transoxiana, pada tanggal 8 April 1336M/25 Sya'ban 736 H, sementara sumber lain (Sulaiman,1985:11) mengatakan tahun 728 H, dan meninggal di Otrar pada tahun 1404 M, Timur Lenk berasal dari keluarga dinasti Mongol dari keturunan Chaghatai ibn Jenghis Khan.

Timur Lenk juga dikenal dengan nama Tamerlane (Bahasa Turki Chagatai: Tēmōr yang berarti "besi"), juga dikenal sebagai Temur, Timur Lenk, Taimur, atau Timur i Leng, yang artinya Timur si Pincang, karena kaki kirinya yang pincang sejak lahir adalah seorang penakluk dan penguasa keturunan Turki Mongol dari wilayah Asia Tengah, yang terkenal pada abad ke-14, terutama di Rusia Selatan dan Persia.

Ayahnya bernama Taragai, kepala suku Barlas, keturunan Karachar Noyan yang menjadi menteri dan kerabat Chaghatai, putera Jenghis Khan, yang sekaligus komandan pasukan tempurnya. Karachar terkenal di antara kaumnya sebagai yang pertama memeluk agama Islam. Teragai mungkin saja mewarisi pangkat yang tinggi diketentaraan, tetapi seperti ayahnya Burkul, ia menggemari kehidupan beragama dan belajar. Di bawah bimbingan yang baik, Timur ketika berusia dua puluh tahun bukan saja mahir dalam kegiatan-kegiatan luar ruangan, tetapi juga mempunyai reputasi sebagai pembaca al Quran yang tekun. Pada masa itu, ia disebutkan telah menunjukkan sifat-sifat yang ramah dan mudah bersimpati.

Suku Barlas mengikuti Chaghatai mengembara ke arah barat dan menetap di Samarkand. Taragai menjadi gebernur Kech. Keluarganya mengaku keturunan Jenghis Khan, adalah hal yang justru tidak diakui sendiri oleh Timur Lenk, sehingga ia lebih suka menggunakan julukan 'pangeran' katimbang nama Khan. Meskipun akhirnya ia menjadi menantunya keluarga Khan, dan mendapat julukan "Gurkan" atau "Kurkan" yang berarti "menantu raja" atau "menantu Khan". 
Melalui catatannya, Timur bercerita, Ayahku berkata kepadaku bahawa kami adalah keturunan dari Abu al-Atrak (Bapaknya bangsa Turki). Dari silsilah itulah terungkap bahawa Timur Lenk masih merupakan keturunan Monggol. Ayahnya bernama Teragai, ketua kaum Barlas. dia adalah cicit dari Karachar Nevian yaitu anak Jenghis Khan. Karachar merupakan pemeluk agama Islam yang pertama di antara kaumnya.

Memang, berbagai riwayat berselisih pendapat tentang ketersambungan nasab Timur Lenk dengan Jenghis Khan ini. Al Qarmani mengatakan masih bersambung ke Jenghis Khan dari Ibu, (al Qarmany, tt: 161) namun kedua sumber pertama bersepakat bahwa realitas sejarah mengatakan bahwa imperium Timur Lenk merupakan perpanjangan dari Mongol dan peradabannya yang merupakan bagian tak terpisahkan dari sejarah dinasti Mongol (Spuler, 1972).

Timur Lenk di masa mudanya dikenal sebagai penunggang kuda dan pemanah yang handal. Sangat berambisi menjadi tokoh di daerahnya. Selain itu juga bergabung dengan militer dalam berbagai peperangan dan penjarahan, Pernah pundak dan pahanya terluka, sehingga kakinya pincang dan salah satu lengannya lumpuh.

Dalam bahasa Mongol, Timur berarti 'besi'. Sedangkan nama belakang Lenk atau Lame adalah julukan yang berarti 'pincang'. Ada beberapa versi yang menyatakan penyebab cacatnya salah satu kaki Timur. Salah satu versi menyebutkan, kakinya cacat sejak lahir. Ada pula yang berkisah, kakinya cacat ketika berperang. Versi lain mengatakan, kaki Timur cacat saat mengembala kambing.

Dunia ketenteraan merupakan pilihan hidupnya, lalu dia pun bergabung sebagai tentera dengan penguasa tempatan, Amir Husein. Pada 1360 M, Timur telah menjadi seorang pemimpin tentera yang mashyur. Timur dikenali sebagai panglima yang gigih dalam mempertahankan wilayahnya dari ancaman Tughluq Timur Khan, penguasa Dinasti Chagatai. Ketangkasan dan kehebatannya membuatkan penguasa Dinasti Chagatai bergidik. Tuglaq lalu menawarkan sebuah jabatan kepada Timur yaitu menjadi pembantu utama (wazir) Gubernur Samarkand, Ilyas. Timur pun menerima tawaran itu. Bersama Amir Husein, Timur lalu melakukan pemberontakan dan mengalahkan pasukan Tuglaq Timur Khan hingga membuat Dinasti Chagatai hancur binasa.

Karier Timur Lenk dalam dunia militer berkembang terus. Sebagai seorang pemuda yang berbakat dan kecacatannya tidak menyurutkan ambisinya terhadap kekuasaan. Kesempatan emaspun datang dikala wilayah di seberang sungai (Oxus) dilanda kurusuhan dan goncangan pasca terbunuhnya pangeran Qazaghan tahun 1358M Dengan kelicikannya, Timur berhasil menaklukkan Tughluq Timur dan Ilyas Khoja, dan kemudian dia juga melawan Amir Hussain (iparnya sendiri). Timur Lenk kemudian berhasil mengambil alih kekuaasan dinasti Chaghatai. Dan kemudian berhasil mendirikan imperium atas namanya sendiri Dinasti Timuriyah setelah dinasti Chaghatai dikalahkan pasukannya dibawah pimpinannya sendiri, Timur Lenk. Dan dia memproklamirkan dirinya sebagai penguasa tunggal di Transoxiana, penerus Dinasti Chagatai dari keturunan Jenghis Khan. 


\section{Imperium Timur Lenk}

Timur Lenk mulai mengatur strategi untuk membangun sebuah imperium Mongol (Raya) yang besar pasca runtuhnya imperium Jenghis Khan. Kekuatan militernya bergerak dari sungai Ghulja Rusia sampai Damaskus Syam dari Ezmir Asia Kecil sampai sungai Gangga di India. Setelah Khuwarezm masuk kekuasannya tahun 781H./1380 M Timur Lenk menyerang Persia tahun 1381M hingga berhasil menundukannya tahun 1386M Dinasti Timuriyah membentang kekuasannya dari kawasan Asia Tengah sampai Timur Tengah, yang dikenal sebagai negeri di seberang sungai, yakni sungai Oxus (ma wara' al-nahr). Bahkan Samarkand kemudian menjadi pusat perdagangan yang berarti, antara Cina, Turkistan, (Hudlari, 1970: 480).

Secara cemerlang, wilayah kekuasaannya terus meluas dan berturut-turut, pada tahun $1386 \mathrm{M}$ Persia digempur. Pasukannya merangkak dari Azarbaijan menuju Georgia dan Arminia. Dan pada tahun 1400M/803H. Timur Lenk dan pasukannya memasuki Baghdad, hingga menguasai Aleppo pada tahun yang sama. Di penghujung tahun 1400M pasukan Timur Lenk memasuki Damaskus, dan sempat mendudukinya selama dua tahun, kemudian meninggalkannya pada tahun $1402 \mathrm{M}$.

Timur Lenk dan pasukannya mampu menundukkan semua kerajaan di wilayah seberang sungai dan Asia Barat yang sempat berdiri dari reruntuhan dinasti Mogoli Persia, adalah hal yang menghantarkan Timur Lenk mampu membangun imperium Mongol Raya mengikuti cara-cara dan strategi politik imperium Mongol yang dibangun pendahulunya Jenghis Khan, yakni politik geneolis yang dibangun di atas prinsip ekspansi, perluasan dan pendudukan kerajaan-kerajaan lain, dengan menteror penduduk, bahkan berupaya menguasai seluruh dunia.

Gambaran yang sama juga diberikan oleh al Qarmani dalam karyanya Akhbar al Duwal wa Atsar al Uwal fi al Tarikh. Al Qarmani memaparkan kisah Timur Lenk dalam sub judul: Fi dzikr Timur wa ma fa'alahu min mafasid al umur. Al Qarmani menggambarkan bagaimana kebengisan Timur Lenk dan pasukannya ketika memasuki sebuah wilayah dan mendudukinya, (Yusuf al Qarmani:165). Sementara Partuld dalam karyanya Tarikh al Turk fi Asia al Wustha, berupaya memaparkan secara detail imperium Timur Lenk, beserta kerusakan-kerusakan yang ditimbulkannya di masing-masing wilayah yang didudukinya, dari Khawarezm, Samarkand, Turkmania, Bukhara, Khazakistan, Uzbekistan, dan Turkistan, (Partuld,1996:246-247).

\section{Ekspedisi dan Ekspansi Timur Lenk}

Setelah lebih dari satu abad umat Islam menderita dan berusaha bangkit dari kehancuran akibat serangan bangsa Mongol di bawah Hulagu Khan, malapetaka yang tidak kurang dahsyatnya datang kembali, yaitu serangan yang juga dari keturunan bangsa Mongol. Berbeda dari Hulagu Khan dan keturunannya pada dinasti Ilkhan, penyerang kali ini sudah masuk Islam, tetapi sisa-sisa kebiadaban dan kekejaman masih melekat kuat. Serangan itu dipimpin oleh Timur Lenk sendiri, yang berarti Timur si Pincang. 
Sejak usia masih sangat muda, keberanian dan keperkasaannya yang luar biasa sudah terlihat. Ia sering diberi tugas untuk menjinakkan kuda-kuda binal yang sulit ditunggangi dan memburu binatang-binatang liar. Sewaktu berumur 12 tahun, ia sudah terlibat dalam banyak peperangan dan menunjukkan kehebatan dan keberanian yang mengangkat dan mengharumkan namanya di kalangan bangsanya. Akan tetapi, baru setelah ayahnya meninggal, sejarah keperkasaannya bermula setelah Jagatai wafat, masing-masing Amir melepaskan diri dari pemerintahan pusat. Timur Lenk mengabdikan diri pada Gubernur Transoxiana, Amir Qazaghan Ketika Qazaghan meninggal dunia, datang serbuan dari Tughluq Temur Khan, pemimpin Moghulistan, yang menjarah dan menduduki Transoxiana. Timur Lenk bangkit memimpin perlawanan untuk membela nasib kaumnya yang tertindas. Tughluq Temur setelah melihat keberanian dan kehebatan Timur, menawarkan kepadanya jabatan gubernur di negeri kelahirannya. Tawaran itu diterima. Akan tetapi, setahun setelah Timur Lenk diangkat menjadi gubernur, tahun $1361 \mathrm{M}$, Tughluq Temur mengangkat puteranya, Ilyas Khoja menjadi gubernur Samarkand dan Timur Lenk menjadi wazirya. Tentu saja Timur Lenk menjadi berang. Ia segera bergabung dengan cucu Qazaghan, Amir Husain, mengangkat senjata memberontak terhadap Tughluq Temur (Wajdi, tt: 729).

Timur Lenk berhasil mengalahkan Tughluq Temur dan Ilyas Khoja. Keduanya dibinasakan dalam pertempuran. Ambisi Timur Lenk untuk menjadi raja besar segera muncul. Karena ambisi itulah ia kemudian berbalik memaklumkan perang melawan Amir Husain, walaupun iparnya sendiri. Dalam pertempuran antara keduanya, ia berhasil mengalahkan dan membunuh Amir Husain di Balkh. Setelah itu, ia memproklamirkan dirinya sebagai penguasa tunggal di Transoxiana, pelanjut Dinasti Chagatai dan keturunan Jenghis Khan, pada 10 April 1370M Sepuluh tahun pertama pemerintahannya, ia berhasil menaklukkan Jata dan Khawarizm dengan sembilan ekspedisi.

Setelah Jata dan Khawarizm dapat ditaklukkan, kekuasaannya mulai kokoh. Ketika itulah Timur Lenk mulai menyusun rencana untuk mewujudkan ambisinya menjadi penguasa besar, dan berusaha menaklukkan daerah-daerah yang pernah dikuasai oleh Jenghis Khan. Ia berkata, Sebagaimana hanya ada satu Tuhan di alam ini, maka di bumi seharusnya hanya ada seorang raja.

Pada tahun $1381 \mathrm{M}$ ia menyerang dan berhasil menaklukkan Khurasan. Setelah itu serbuan ditujukan ke arah Herat. Di sini ia juga keluar sebagai pemenang. Ia tidak berhenti sampai di situ, tetapi terus melakukan serangan ke negeri-negeri lain dan berhasil menduduki negeri-negeri di Afghanistan, Persia, Fars dan Kurdistan. Di setiap negeri yang ditaklukkannya, ia membantai penduduk yang melakukan perlawanan. Di Sabzawar, Afghanistan, bahkan ia membangun menara, disusun dari 2000 mayat manusia yang dibalut dengan batu dan tanah liat. Di Isfa, ia membantai lebih kurang 70.000 penduduk. Kepalakepala dari mayat-mayat itu dipisahkan dari tubuhnya dan disusun menjadi menara. Dari sana ia melanjutkan ekspansinya ke Irak, Syria dan Anatolia (Turki). Tahun 1393 Mia menghancurkan dinasti Muzhaffari di Fars dan membantai amiramirnya yang masih hidup. Pada tahun itu pula Baghdad dijarahnya, dan setahun kemudian ia berhasil menduduki Mesopotamia. Penguasa Baghdad itu, Sultan 
Ahmad Jalair, melarikan diri ke Syria. Ia kemudian menjadi Vassal dari Sultan Mesir, Al Malik al Zahir Barquq. Penguasa dinasti Mamalik yang berpusat di Mesir ini adalah satu-satunya raja yang tidak mau dan tidak berhasil ditundukkannya. Utusan-utusan Timur Lenk yang dikirim ke Mesir untuk perjanjian damai, sebagian dibunuh dan sebagian lagi diperhinakan, kemudian disuruh pulang ke Timur Lenk. Mesir, sebagaimana pada masa serangan-serangan Hulagu Khan, kembali selamat dari serang bangsa Mongol. Karena Sultan Barquq tidak mau mengekstradisi Ahmad Jalair yang berada dalam perlindungannya, Timur Lenk kemudian melancarkan invasi ke Asia Kecil menjarah kota-kota, Takrit, Mardin dan Amid. Di Takrit, kota kelahiran Salahuddin al Ayyubi, ia membangun sebuah piramida dari tengkorak kepala korban-korbannya (Kotler, 1974: 699-670)

Pada tahun $1395 \mathrm{M}$ ia menyerbu daerah Qipchak, kemudian menaklukkan Moskow yang didudukinya selama lebih dari setahun. Tiga tahun kemudian ia menyerang India. Konon alasan penyerbuannya adalah karena ia menganggap penguasa muslim di daerah ini terlalu toleran terhadap penganut Hindu. Ia sendiri berpendapat, semestinya penguasa muslim itu memaksakan Islam kepada penduduknya. Di India ia membantai lebih dari 80.000 tawanan. Dalam rangka pembangunan masjid di Samarkand, ia membutuhkan batu-batu besar. Untuk itu, 90 ekor gajah dipekerjakan mengangkat batu-batu besar itu dari Delhi ke Samarkand.

Setelah pondasi masjid dibangun, tahun 1399M Timur Lenk berangkat memerangi Sultan Mamalik di Mesir yang membantu Ahmad Jalair, penguasa Mongol di Baghdad yang lari ketika ia menduduki kota itu sebelumnya, dan memerangi Kerajaan Usmani di bawah Sultan Bayazid I. Dalam perjalanannya itu, ia menaklukkan Georgia. Di Sivas, Anatolia sekitar 4000 tentara Armenia dikubur hidup-hidup untuk memenuhi sumpahnya bahwa darah tidak akan tertumpah bila mereka menyerah.

Pada tahun $1401 \mathrm{M}$ ia memasuki daerah Syria bagian utara. Tiga hari lamanya Aleppo dihancurleburkan. Kepala dari 20.000 penduduk dibuat piramida setinggi 10 hasta dan kelilingnya 20 hasta dengan wajah mayat menghadap keluar. Banyak bangunan seperti sekolah dan masjid yang berasal dari zaman Nuruddin Zanki dan Ayyubi dihancurkan. Hamah, Horns dan Ba'labak berturut-turut jatuh ketangannya. Pasukan Sultan Faraj dari Kerajaan Mamalik dapat dikalahkannya dalam suatu pertempuran dahsyat sehingga Damaskus jatuh ke tangan pasukan Timur lenk pada tahun 1401 M Akibat peperangan itu masjid Umayyah yang bersejarah rusak berat tinggal dinding-dindingnya saja yang masih tegak. Dari Damaskus para seniman ulung dan pekerja atau tukang yang ahli dibawanya ke Samarkand. Ia memerintahkan ulama yang menyertainya untuk mengeluarkan fatwa membenarkan tindakan-tindakannya itu. Setelah itu serangan dilanjutkan ke Baghdad. Ketika Baghdad berhasil ditaklukkan, ia melakukan pembantaian besarbesaran terhadap 20.000 penduduk sebagai pembalasan atas pembunuhan terhadap banyak tentaranya sewaktu mengepung kota itu. Di sini, seperti kebiasaannya, ia kemudian mendirikan 120 buah piramida dari kepala mayat-mayat sebagai tanda kemenangan. 
Kerajaan Usmani, oleh Timur Lenk dipandang sebagai tantangan terbesar, karena kerajaan ini menguasai banyak daerah bekas imperium Jenghis Khan dan Hulagu Khan. Bahkan, Sultan Bayazid, penguasa tertinggi kerajaan ini sebelumnya berhasil meluaskan daerah kekuasaannya ke daerah-daerah yang sudah ditaklukkan oleh Timur Lenk. Karena itu Timur Lenk sangat berambisi mengalahkan kerajaan ini. Ia mengerahkan bala tentaranya untuk memerangi tentara Bayazid I. Di Sivas terjadi peperangan hebat antara kedua pasukan itu. Timur Lenk keluar sebagai pemenang dan putera Bayazid I, Erthugrul, terbunuh dalam pertempuran tersebut. Pada tahun 1402 M terjadi peperangan yang menentukan di Ankara. Tentara Usmani kembali menderita kekalahan, sementara Sultan Bayazid sendiri tertawan ketika hendak melarikan diri. Bayazid akhirnya meninggal dalam tawanan. Timur Lenk melanjutkan serangannya ke Broessa, ibu kota lama Turki, dan Syria. Setelah itu ia kembali ke Samarkand untuk merencanakan invasi ke Cina. Namun, di tengah perjalanan, tepatnya di Otrar, ia menderita sakit yang membawa kepada kematiannya. Ia meninggal tahun $1404 \mathrm{M}$, dalam usia 71 tahun. Jenazahnya dibawa ke Samarkand untuk dimakamkan dengan upacara kebesaran.

Sekalipun ia terkenal sebagai penguasa yang sangat ganas dan kejam terhadap para penentangnya, sebagai seorang muslim Timur Lenk tetap memperhatikan pengembangan Islam. Bahkan dikatakan, ia seorang yang saleh. Konon, ia adalah penganut Syiah yang taat dan menyukai tasawuf tarekat Naqsyabandiyyah. Dalam perjalanan-perjalanannya ia selalu membawa serta ulama-ulama, sastrawan dan seniman. Ulama dan ilmuwan dihormatinya. Ketika berusaha menaklukkan Syria bagian utara, ia menerima dengan hormat sejarawan terkenal, Ibnu Khaldun yang diutus Sultan Faraj untuk membicarakan perdamaian. Kota Samarkand diperkayanya dengan bangunan-bangunan dan masjid yang megah dan indah. Di masa hidupnya kota Samarkand menjadi pasar internasional, mengambil alih kedudukan Baghdad dan Tabriz. Ia datangkan tukang-tukang yang ahli, seniman-seniman ulung, pekerja-pekerja yang pandai dan perancangperancang bangunan dari negeri-negeri taklukannya; Delhi, Damaskus dan lainlain. Ia meningkatkan perdagangan dan industri di negerinya dengan membuka rute-rute perdagangan yang baru antara India dan Persia Timur. Ia berusaha mengatur administrasi pemerintahan dan angkatan bersenjata dengan cara-cara rasional dan berjuang menyebarkan Islam

Timur Lenk menghabiskan waktunya selama 35 tahun dalam berbagai pertempuran dan ekspedisi. Didukung pasukan Turki yang loyalis dan para tokoh muslim serta ulama, Timur pun melakukan perluasan kekuasaan. Dia melebarkan kekuasaannya ke wilayah barat dan barat laut meliputi Mongol, Laut Kaspia, Ural, dan Volga. Ekspedisi yang dilakukannya ke wilayah selatan dan barat daya mampu menaklukkan setiap provinsi di Persia, termasuk Baghdad, Karballa, dan Irak Utara. Tak heran, bila banyak kota dan daerah yang dikuasai dinasti lain berhasil dikuasai Timur. Salah satu lawan yang paling berat bagi Timur adalah Tokhtamysh.

Wilayah Khawarizmi dan Jata berhasil dikuasai pasukan Timur pada 1380M setelah melalui pertempuran panjang selama 10 tahun. Sepanjang 1381M1382 M, Timur sudah menaklukkan wilayah kekuasaan Kerajaan Persia seperti 
Herat, Masyhad, Sabzavar, Astarabad, Mazandaran, dan Sistan. Pada tahun 1382M, pasukan Timur berhasil membantu Tokhtamysh untuk menundukkan Moskow. Pasukan Tokhtamysh yang dibantunya ternyata balik menyerang pasukan Timur dan menginvasi Azerbaijan pada $1385 \mathrm{M}$ Dalam sebuah pertempuran yang dahsyat, kekuatan Tokhtamysh akhirnya berakhir dipatahkan. Guna menghadapi pasukan lawannya itu, Timur memimpin tak kurang dari 100.000 pasukan yang menempuh perjalanan beratus-ratus mil. Sekitar 100.000 pasukannya yang bergerak dari Timur sejauh ratusan mil nyaris mengalami kelaparan. Untunglah, Timur memerintahkan pasukannya untuk berburu hingga akhirnya tak sempat mengalami kelaparan. Pasukan Tokhtamysh akhirnya terpojok di wilayah Orenburg dan berhasil dikalahkan pasukan Timur.

Pada 1398M, Timur melakukan ekspedisi penaklukan ke India. Ia mendengar terjadi perang sipil di wilayah India. Saat itu, di India terdapat kerajaan Islam bernama Dinasti Tughlaq yang dipimpin Sultan Nashir al Din Mahmud. Timur mendengar Sultan Delhi Muslim itu terlalu toleran dan bersikap lemah terhadap masyarakat Hindu. Timur lalu memutuskan untuk mengambil alih kekuasaan Sultan Delhi. Pasukannya melintasi Sungai Indus di Attock pada 24 September 1398 M Pasukan Sultan dengan mudah dikalahkan pada 17 Desember 1398M Dia menuliskan penaklukannya di India dalam Tuzuk Timuri.

Sayangnya, penaklukan Delhi itu diwarnai dengan pertumpahan darah yang sebenarnya tak perlu dilakukan Timur. Dia meninggalkan Delhi pada Januari 1399M Menurut Ruy Gonzales de Clavijo, Timur membawa 90 ekor gajah dari Delhi untuk mengangkut batu mulia. Dia lalu menggunakannya untuk membangun masjid di Samarkand. Para sejarawan meyakini masjid itu adalah Masjid Bibi-Khanym. Setelah itu, dia berperang dengan Yildirim Bayezid I, Sulthan Kerajaan Utsmani, dan sulthan Mamluk dari Mesir. Pada 1400M, Timur menyerbu Armenia dan Georgia. Setahun kemudian, dia menginvasi Baghdad. Sekitar 20 ribu orang tewas dalam invasi itu. Timur tutup usia pada 19 Februari 1405M saat melakukan pertempuran melawan Dinasti Ming.

Setelah Timur Lenk meninggal, dua orang anaknya, Muhammad Jehanekir dan Khalil, berperang memperebutkan kekuasaan. Khalil (1404-1405M) keluar sebagai pemenang. Akan tetapi, ia hidup berfoya-foya menghabiskan kekayaan yang ditinggalkan ayahnya. Karena itu saudaranya yang lain, Syah Rukh (14051447M), merebut kekuasaan dari tangannya. Syah Rukh berusaha mengembalikan wibawa kerajaan. Ia seorang raja yang adil dan lemah lembut. Setelah wafat, ia diganti oleh anaknya Ulugh Bey (1447-1449M), seorang raja yang alim dan sarjana ilmu pasti. Namun, masa kekuasaannya tidak lama. Dua tahun setelah berkuasa ia dibunuh oleh anaknya yang haus kekuasaan, Abdal-Latif (1449- 1450 M). Raja besar dinasti Timuriyah yang terakhir adalah Abu Sa'id (1452-1469M). Pada masa inilah kerajaan mulai terpecah belah. Wilayah kerajaan yang luas itu diperebutkan oleh dua suku Turki yang baru muncul ke permukaan, Kara Koyunlu (domba hitam) dan Ak Koyunlu (domba putih). Abu Sa'id sendiri terbunuh ketika bertempur melawan Uzun Hasan, penguasa Ak Kdyunlu.

\section{Strategi Politik Timur Lenk: Militerisasi Negara (Attack and Defend)}


Mencermati sepak terjang Timur Lenk dalam ekspedisi-ekpedisi dan ekspansinya ke luar wilayah Samarkand, dapatlah ditarik sebuah benang merah, bahwa di samping dilatarbelakangi oleh ambisi pribadinya untuk menguasai dunia seperti yang pernah dilakukan oleh buyutnya Jenghiz Khan dan Hulagu Khan, Timur Lenk sangat ambisius untuk mendirikan sebuah imperium Mongol Raya seperti yang telah disinggung di muka.

Kalau Jenghiz Khan telah berhasil membangun sebuah kekaisaran dunia di atas puing-puing reruntuhan kota-kota yang ditundukkannya. Keganasan pemimpin-pemimpin Mongol ala Jenghiz Khan dan Hulagu Khan merupakan sebuah teknik dan strategi yang tidak hanya untuk memperluas wilayah kekuasaannya, juga untuk memperkokoh eksistensinya, meskipun tentu melahirkan kebencian penduduk kota yang disinggahinya. Seperti yang disitir Sulaiman dalam karyanya Timur Link wa Dawlat al-Mamalik al-Garakisah, bahwa ketika Muhammad, syah Turki Khawarazmian (1200-1220M) berusaha membangun sebuah kekhalifan muslim sendiri di Iran dan kawasan Oxus, jenderal Mongol Hulagu Khan melihatnya sebagai tindakan yang menghina. Adalah hal yang menyebabkan 1219 hingga 1229 tentara Mongol mengejar Muhammad dan putranya Jalal al din di seluruh Iran, melalui Azerbaijan dan Syria, yang senantiasa meninggalkan jejak kematian dan kehancuran di belakang mereka. Dan pada tahun $1231 \mathrm{M}$ mulailah serangkaian serangan baru. Sebuah kota Muslim yang besar dihancurkan. Bukhara diubah menjadi sampah, Baghdad jatuh setelah mengalami sebuah pertempuran dan membawa serta kekhalifahannya. Mayatmayat bergeletakan di jalan-jalan, dan sebagian penduduk mengungsi ke Syria, Mesir, atau India (Sulaiman, tt: 133-134).

Penguasa Muslim pertama yang mampu menghentikan langkah Mongolia adalah Baibar, sultan Mesir baru yang membawa nama Mamalik, yang saat itu mendominasi tentara daulah Ayyubiyyah yang didirikan oleh Shalah al-din pada tahun 1250M Para pembesar dinasti Mamalik memimpin sebuah serangan yang sukses terhadap negara Ayyubiyyah dan mendirikan imperium mereka sendiri di Timur Dekat (al-Suyuthi, tt:433). Pada tahun 1260 M Baibar mengalahkan tentara Mongol di Ain Jalut di Palestina Utara (Bernard, 1976:84-85). Setelah serangan mendadak mereka mereka ke India ditangkis oleh kesultanan baru yang berpusat di Delhi, orang-orang Mongol kemudian menetap untuk menikmati kemenangan mereka, dan menciptakan banyak imperium di kantung-kantung kekuasaan Islam berkat raja Kubilai Khan, orang Mongol Khan di Cina (Joesoef, 1978: 300-301).

Pada saat fisiknya lemah Jenghiz Khan membagi wilayah kekuasaannya menjadi empat wilayah kepada empat orang putranya: Juchi, Chaghatai, Ogotai dan Tuli, yang kemudian menjadi empat negara besar. 1) Keturunan Hulagu, yang dikenal sebagi Il Khan (wakil Khan tertinggi), meskipun mulanya mereka menolak, sebelum akhirnya menerimanya dan kemudian menarik diri ke kerajaan mereka di lembah sungai Tingris Efrat dan kawasan pegunungan Iran. 2) Chaghatai mendirikan sebuah negara di laut Syr Oxus setelah menguasai kembali daerah-daerah Islam yang pernah ditaklukkan, seperti Ili, Ferghana, Ray, Hamazan, dan Azerbaijan, sementara 3) White Hord didirikan di kawasan Irtysy, dan 4) Juchi Khan menguasai Golden Horde didirikan di sekiling sungai Wolga, Eropa Timur dan Eropa Tengah. Dari raja inilah muncul seorang tokoh yang 
bernama Barka Khan (1256-1266M) adalah tokoh pertma keturunan Jenghiz Khan yang memeluk Islam (Arthur, 1983: 116)

Ada hal penting yang perlu dicatat di sini, bahwa orang-orang Mongolia tidak memaksakan agama dan spiritualiatas mereka di atas wilayah kekuasaan mereka ketika mereka menaklukkan suatu daerah. Mereka justru membangun negeri di atas prinsip kedaerahan, bahkan pada akhir abad 13 dan awal abad ke 14, keempat raja Mongol telah masuk Islam, termasuk diantaranya Timur Lenk.

Karena itu, pada berkembangan berikutnya, orang-orang Mongolia menjadi kekuatan Muslim terpenting di kantung-kantung Islam pusat. Tapi apapun keyakinan resmi mereka terhadap Islam, tetapi ideologi utama dari negara yang mereka dirikan adalah Mongolisme, yang bermimpi menaklukkan dunia dan mengagungkan kekuatan kerajaan dan militer Mongol. Seluruh negara dijalankan dari garis militer. Raja adalah komandan militer dan diharapkan memimpin sendiri anak buahnya dan tidak menyerahkan tugas pada wakilnya.

Dengan demikian di masa awal sebuah pemerintahan Mongol tidak ada ibukota. Ibukota adalah di manapun Khan dan tentaranya mendirikan markas. Aparat negara dijalankan seperti angkatan bersenjata, dan pihak administrasi menyertai tentara dalam perjalanan mereka. Seluruh budaya markas yang rumit dijalankan dengan efisiensi yang cukup jelas.

Ada dua tujuan politik pokok dari seluruh pemimpin-pemimpin Mongol, termasuk di dalamnya Timur Lenk: Pertama, hegemoni dunia dan menjaga keabadian dinasti penguasa mereka, yang membenarkan segala bentuk kekejaman dan kebiadaban. Adalah sebuah ideologi yang sama dengan politik absolutisme kuno, yang percaya bahwa semakin besar kekuasaan penguasa, semakin baiklah perdamaian dan keamanan negara tersebut.

Kedua, Masuknya Mongol ke dunia muslim merupakan hal yang traumatis. Mongol meninggalkan penderitaan berupa puing-puing dan berbagai reruntuhan perpustakaan, serta resesi ekonomi. Tetapi setelah mereka mencapai kemenangan, orang-orang Mongol itu membangun kembali kota-kota yang telah mereka hancurkan dengan skala yang luar biasa besar mendirikan istana-istana megah, mengajarkan ilmu pengetahuan, kesenian, sejarah dan tasawuf (Musyrifah, 2004:191-202). Mereka hampir saja menaklukkan dunia, dan menunjukkan jenis imperialism baru, yang menghubungkan kemungkinan aturan universal dengan perusakan masal.

Adalah hal yang sama juga diakui oleh Musyrifah Susanto bahwa penaklukan Mongol atas wilayah negara-negara Islam hampir memusnahkan segala unsur Arab dan bahasanya, serta agama Islam. Dengan tindakan pemusnahan, pembakaran dan pembunuhan, sempurnalah kehancuran setiap kota yang didudukinya beserta peradabannya. Namun satu hal yang luar biasa, bahwa merekalah yang meruntuhkannya dan dari mereka pulalah yang membangun kembali peradaban itu.

Timur Lenk, yang merupakan salah satu keturunan Jenghiz Khan misalnya, pada akhir hayatnya memeluk Islam, berkat usaha sultan Faraj, salah seorang raja dinasti Mamluk yang mengutus delegasi yang dipimpin langsung oleh sosiolog dan sejarawan muslim Ibn Khaldun. Setelah keislamannya itu, 
kekejaman Timur Lenk mereda dan ia mengamalkan ajaran Islam secara tekun dan membelanya dengan semangat sampai ajal menjemputnya tahun 1404M

Dan hal ini diikuti oleh pemimpin-pemimpin Mongol yang lain, Barka Khan (1256-1266) misalnya, menurut Arnold dalam The Preacing of Islam, merupakan keturunan Jenghiz Khan yang pertama-tama masuk Islam Ia banyak membangun rumah-rumah ibadah dan perguruan-perguruan tinggi Islam di kotakota belahan Utara. Hubungan antara Mongolia dan Mesir semakin erat, adalah hal yang kemudian menjadikan misi Islam dari Mesir berdatangan dan Islam semakin tersiar di wilayah kekuasaan Mongol (Arnold, 1995: 229).

\section{Simpulan}

Dari uraian singkat di atas, nampak jelas bahwa Timur Lenk, meskipun berbeda agama dengan para pendahulunya yang tetap menjujung tinggi agama Syamanisme, terutama Jenghiz Khan dan Hulagu Khan, tetap mewarisi tradisi Mongolisme, yang senantiasa membawa kerusakan dan kehancuran di setiap wilayah yang ditaklukkannya. Sebuah kekuatan dahsyat yang dilatarbelakangi ambisi untuk menguasai dunia. Setiap melewati sebuah kota, diluluhlantakkan kota itu, untuk kemudian dikuasainya. Inilah yang disebut sebagai politik serang dan bertahan (attack and defend).

Militerisasi negara, di mana semua aktifitas pemerintahan di bawah komando militer merupakan hal yang unik, bahkan seorang raja yang berperan sekaligus sebagai seorang pemimpin perang menjadi karakter yang melekat pada tradisi Mongolisme, termasuk di dalamnya Timur Lenk.

Dan in fact, Timur Lenk dan pasukannya mampu menundukkan semua kerajaan di wilayah seberang sungai dan Asia Barat yang sempat berdiri dari reruntuhan dinasti Mogoli Persia, adalah hal yang menghantarkan Timur Lenk mampu membangun imperium Mongol Raya mengikuti cara-cara dan strategi politik imperium Mongol yang dibangun pendahulunya Jenghis Khan, yakni politik geneolis yang dibangun di atas prinsip ekspansi, perluasan dan pendudukan kerajaan-kerajaan lain, dengan menteror penduduk, bahkan berupaya menguasai seluruh dunia.

Dari sinilah, Timur Lenk muncul di atas peta sejarah Islam sebagai sosok yang hujat sekaligus dipuja. Dalam pengertian bahwa setelah mereka mencapai kemenangan di atas puing-puing kehancuaran, pemimpin Mongol itu segera membangun kembali kota-kota yang telah mereka hancurkan dengan sekala yang luar biasa besar. wa Allah a'lam bi al-shawab.

\section{DAFTAR PUSTAKA}

Al-Suyuthi, Jalal al-Din. Tt. Tarikh al-Khulafa'. Beirut: Dar al-Fikr. 
Al Qarmany, Ahmad Yusuf. Tt. Akhbar al-Duwal wa Atsar al-Uwal fi al-Tarikh. Tanpa Tempat: 'Alam al-Kutub.

Armstrong, Karen. 2002. Islam Sejarah Singkat (Islam:A Short History). Terjemahan Fungky Kusnaedy Timur. Yogyakarta: Penerbit Jendela

Arnold, Thomas W. 1995. The Preaching of Islam: A History of Propagation of The Muslim Faith. New Delhi: Low Price Publication.

Arthur, Goldschmidt, Jr. 1983. A Concise History of Midle East. Colorado: Westview Press.

Bernard, Lewis. 1993. Islam in History: Ideas, People, and Events in The Middle East. New Edition, Ervised, and Expanded. Chicago: Open Court.

------. 1976. Islam from The Prophet Muhammad to The Capture of Constantinopel: Politik and War. London: The Macmillan Press Ltd.

Fisrt Encyclopedia of Islam. Tt. Vol. 7. London: E.J. Brill.

Hasan, Ibrahim Hasan. Tt. Tarikh al-Islam al-Siyasi wa al-Dini wa al-Tsaqafi wa al-Ijtima'I. Beirut: Dar al-Jeil.

Hudlari, Muhammad. 1970. Muhadlarat Tarikh al-Umam al-Islamiyyah. Kairo: Al-Maktabah al-Kubra.

Joesoef, Sou'yb. 1978. Sejarah Daulah Abbasiyyah. Jilid III. Jakarta: Bulan Bintang.

Kotler, Hitti, Philip. 1974. History of Arabs. London: Macmillan Student Editions.

Lapidus, Ira. M. 1999. Sejarah Sosial Umat Islam (A History of Islamic Societies). Terjemahan Ghufron A. Mas'adi. Bagian Kedua. Jakarta: PT. Raja Grafindo Persada.

Majalah al-Trikh al-'Arbi. Maktabah Shamilah. http://www.shamila.com.

Musyrifah, Sunanto. 2004. Sejarah Islam Klasik: Perkembangan Ilmu Pengetahuan Islam. Jakarta: Prenada Media.

Partuld, W. 1996. Tarikh al-Turk fi Asia al-Wustha. Kairo: Al-Ha`ah alMishriyyah al-'Ammah li al-Kitab.

Saunders, J.J. 1965. A History of Medieval Islam. London and New York: Roudledge. 
Spuler, Bertold. 1972. History of the Mongols (Based on Eastern and Western Accounts of the Thirteenth and Fourteenth Centuries). Translated from the Germanby Helga and Stuart Drummond. The Islamic World Edited by G.E. von Grunebaum. London: Routledge \& Kegan Paul.

Sulaiman, Ahmad ibn Abd al-Karim. 1985. Timur Link wa Dawlat al-Mamalik alGraksah. Beirut: Dar al-Nahdlah al-'Arabiyyah.

Syalabi, Ahmad. 1979. Mausu'ah al-Tarikh al-Islami wa al-Hadlarah alIslamiyyah. Juz VII. Kairo: Maktabah al-Nahdlah al-Mishriyyah.

Wajdi, M. farid. tt. Dairat al-Ma'arif li al-Qarn al-'Isyrin. Jilid 2. Beirut: AlMaktabah al-'Ilmiyyah al-Jadidah. 